\title{
DAYA TAHAN SEKTOR RUMAH TANGGA DALAM RANGKA MENJAGA STABILITAS SISTEM KEUANGAN
}

\author{
Ita Rakhmawati \\ STAIN Kudus \\ rakhmaita@gmail.com \\ Suhadi \\ STAIN Kudus \\ Salwalubna44@gmail.com
}

\begin{abstract}
The crisis in 1997 is the image of the high rise in inflation in Indonesia. The phenomenon of inflation when it reached $82.40 \%$ (Anas, 2006). The early mid-1998 also experienced a weakening of the rupiah against the dollar. Condition stable economy is the desire of each country in comparison with the state of the economy has always fluctuated. Economic stability will create an atmosphere conducive economy. stable climatic conditions in the expected level of welfare is the purpose in each country. One of the efforts to maintain economic stability is through monetary policy. For example, with economic growth, maintain price stability (inflation), the achievement of the balance of payments and the reduction of unemployment (Natsir, 2008). The stability of the financial system of a country of which reflected their price stability, in the sense that there are a great price that can be harmful to society, both consumers and manufacturers that will damage the joints of the economy. However, the implementation of the policy, Bank Indonesia as the monetary authority uses monetary variables such as interest rates and the money supply to cope with economic shocks such as inflation. Besides the need for the government's role in maintaining the rupiah to avoid turmoil in the economy. The importance of inflation control based on the consideration that the high inflation and unstable negative impact on socio-economic conditions of society. Among the high inflation will cause a decline in the real income of the community so that the standard of living of the people down and eventually make everyone, especially the poor get poorer. From one of the effects of inflation are so wide will impact people's demands to meet the needs of more and more difficult. Their continuous
\end{abstract}


price increases being offset by rising income of the communities, it can make sure the Indonesian state would worsen. As a result many people's needs can not be met, so many things that must be met by way of credit. The number of community needs that must be met will cause world of opportunities for banks to offer credit readily available to meet the needs. The third object of research above (inflation, poverty, and credit) does affect the stability of the financial system? In this study using secondary data from the Badan Pusat Statistik (BPS) and Bank Indonesia (BI) with time series data from the years 2007-2015. The process of data analysis was performed using OLS regression with Eviews 8.0. Based on research, if only partial test of the poverty variable significantly affect the stability of the financial system amounted to 2,023 with $a=10 \%$. Meanwhile, two other variables (inflation and poverty) is not significant to the stability of the financial systemMeanwhile, two other variables (inflation and poverty) is not significant to the stability of the financial system. While the value of $R$-Square (0.629900), indicating that the three independent variables / free consisting of inflation, poverty and credit simultaneously have the effect that make the stabilization of the financial system increases or decreases. That is jointly independent variables (inflation, poverty and loans) contributed / effect of $62.9 \%$ against the stability of the financial system. The rest is the influence of other factors beyond the three independent variables studied.

Keywords: Stabilization Of The Financial System, Inflation; Poverty

\section{A. Pendahuluan}

Terjadinya krisis pada tahun 1997 adalah gambaran tingginya kenaikan inflasi di Indonesia. Fenomena inflasi pada saat itu mencapai 82,40\% (Anas, 2006). Awal pertengahan tahun 1998 nilai tukar Rupiah terhadap Dollar juga mengalami penurunan. Perekonomian yang stabil adalah tujuan setiap negara dibanding dengan keadaan ekonomi yang selalu fluktuatif. Kestabilan ekonomi akan menciptakan suasana perekonomian yang kondusif. Keadaan yang kondusif akan meningkatkan iklim usaha dan memicu pertumbuhan ekonomi negara. Adanya iklim yang stabil di harapkan tingkat kesejahteraan masyarakat yang menjadi tujuan pada setiap negara. Salah satu upaya menjaga kestabilitas perekonomian adalah melalui kebijakan moneter. Misalnya dengan pertumbuhan ekonomi, menjaga stabilitas harga (inflasi), tercapainya keseimbangan neraca pembayaran dan pengurangan pengangguran (Natsir,2008). 
Pengendalian tingkat inflasi atau menjaga kestabilan harga merupakan salah satu masalah utama dalam makro ekonomi, disamping beberapa masalah penting lainnya seperti mencapai tingkat pertumbuhan ekonomi yang tinggi, mengatasi masalah pengangguran, menjaga keseimbangan neraca pembayaran dan pendistribusian pendapatan yang adil dan merata. Masalah inflasi menjadi indikator yang sangat penting, fenomena inflasi banyak menjadi perhatian para ekonom. Stabilitas sistem keuangan suatu negara di antaranya tercermin dari adanya stabilitas harga, dalam arti tidak terdapat harga yang besar yang dapat merugikan masyarakat, baik konsumen maupun produsen yang akan merusak sendi-sendi perekonomian. Namun adanya penerapan kebijakan tersebut, Bank Indonesia selaku otoritas moneter menggunakan variabel moneter seperti suku bunga dan jumlah uang yang beredar untuk mengatasi gejolak perekonomian seperti inflasi. Selain itu perlunya peran pemerintah dalam menjaga nilai tukar Rupiah agar tidak terjadi gejolak dalam perekonomian.

Pengendalian inflasi sangat penting menjadi salah satu perhatian pemerintah karena beberapa alasan. Pertama, inflasi akan memperburuk distribusi pendapatan (menjadi tidak seimbang). Kedua, inflasi menyebabkan tabungan domestik yang merupakan sumber dana investasi bagi negara-negara berkembang. Ketiga, inflasi mengakibatkan terjadinya defisit dapat menimbulkan ketidakstabilan politik. Inflasi yang terjadi di Indonesia dari tahun ke tahun mengalami fluktuasi yang sangat berpengaruh pada sektor lain. Jika dilihat dari data yang disajikan, inflasi tertinggi terjadi pada tahun 2008 diakibatkan dari sisi penawaran (cost push inflation), sisi permintaan (demand pull inflation) dan sisi ekspektasi inflasi.

Faktor-faktor pendorong terjadinya cost push inflation dapat disebabkan oleh depresiasi nilai tukar, dampak inflasi luar negeri terutama negara - negara partner dagang, peningkatan harga-harga komoditi yang diatur pemerintah (adminitered price, seperti BBM, TDL, tarif telepon, cukai rokok, dan tarif angkutan), dan terjadi negative supply shocks, seperti gagal panen dan langkanya komiditi tertentu akibat bencana alam dan terganggunya distribusi. Halhal tersebut otomatis membuat biaya produksi naik dan harga meroket. Selain faktor cost push inflation, ada peran dari demand 
pull inflation adalah tingginya permintaan barang dan jasa relatif terhadap ketersediannya. Dengan kata lain, banyaknya uang beredar di masyarakat yang melebihi jumlah produksi barang dan jasa merupakan pemicu terjadinya inflasi jenis ini.

Sementara pada faktor ekspektasi inflasi dipengaruhi oleh perilaku masayarakat dan pelaku ekonomi apakah lebih cenderung bersifat adaptif atau forward looking. Hal tersebut tercermin dari perilaku pembentukan harga di tingkat produsen dan pedagang terutama pada saat menjelang hari-hari besar keagamaan (lebaran, natal dan tahun baru) dan penentuan upah minimum provinsi (UMP). Penyumbang inflasi terbesar tahun 2008 adalah banyaknya dari sisi cost push inflation. Meningkatnya harga minyak dunia yang akhirnya memaksa pemerintah untuk mengikuti kenaikan harga BBM pada bulan Mei 2008 memberikan kontribusi yang sangat signifikan terhadap tingkat inflasi, walaupun efek kenaikan harga BBM tersebut sudah tidak signifikan lagi pada bulan Juli 2008 (tabel. 1). Selain itu, meningkatnya harga komoditas pangan dunia (kebutuhan bahan pangan import seperti kedelai, jagung, dan terigu), sejak akhir tahun 2007 yang otomatis meningkatnya biaya pokok produksi perusahaan juga memberikan kontribusi angka inflasi yang sangat besar. Hal lain yang menjadi dasar inflasi adalah kelangkaan sumber energi baik gas maupun minyak di berbagai daerah maupun kekurangan suplai listrik yang mengharuskan terjadinya pemadaman juga memiliki peran dalam kenaikan inflasi karena mendorong pembengkakan biaya produksi.

\section{Tabel. 1}

Tingkat Inflasi Indonesia 2005- 2016

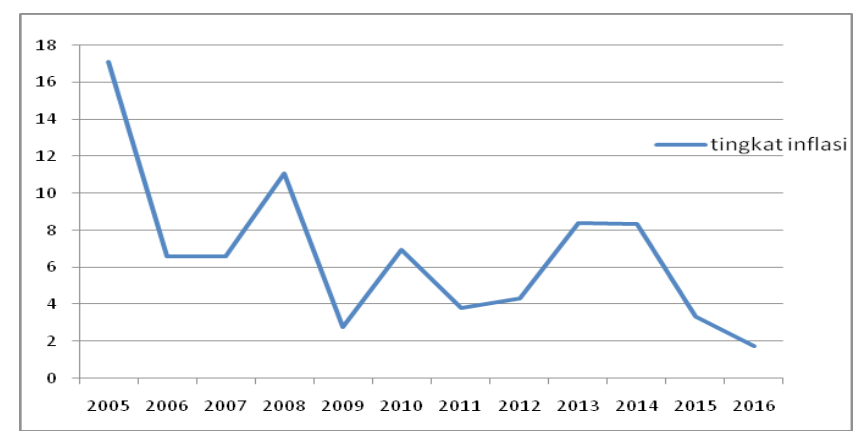

Sumber: BPS Indonesia, 2017 
Pentingnya pengendalian inflasi didasarkan pada pertimbangan bahwa inflasi yang tinggi dan tidak stabil memberikan dampak negatif pada kondisi sosial ekonomi masyarakat. Diantaranya inflasi yang tinggi akan menyebabkan turunnya pendapatan riil masyarakat sehingga standar hidup dari masyarakat turun dan akhirnya menjadikan semua orang, terutama orang miskin bertambah miskin. Dari salah satu dampak inflasi yang begitu luas akan berdampak tuntutan masyarakat untuk memenuhi kebutuhan semakin sulit. Hal tersebut dapat dilihat dari data bahwa adanya kenaikan inflasi mengakibatkan kenaikan pula pada jumlah kemiskinan.

Tabe. 2

Tingkat Kemiskinan Warga Negara Indonesia

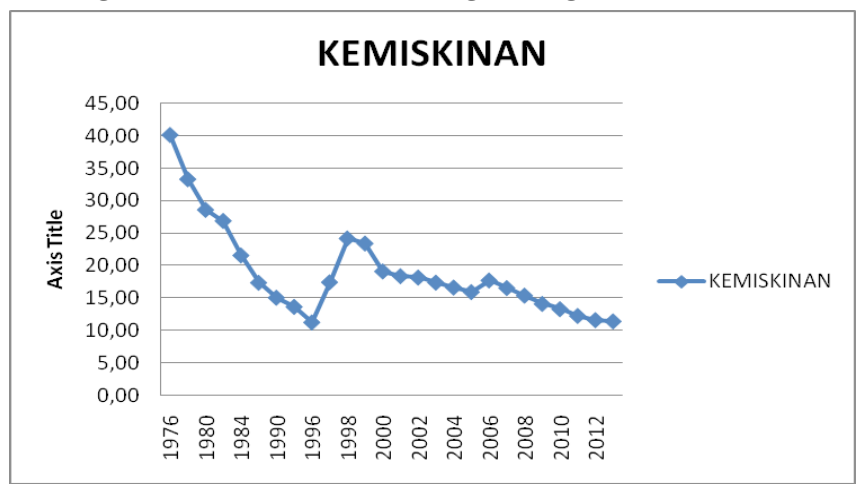

Sumber: Data BPS Indonesia diolah 2017

Jika di lihat dari tabel. 2 menyatakan bahwa krisis terbesar adalah tahun 1998 yang disebabkan oleh krisis tahun awal 1998 yang disebakan anjloknya nilai rupiah menjadi 9.100 - 9.800, Maret 1998 menjadi Rp. 8.600 - 11.000 dan pada akhir tahun 1998 bulan Oktober menjadi Rp.7800 - 14.800 dan setelah itu nilai rupiah naik turun terus sehingga akibatnya daya beli masayarakat menurun dan menyebabkan kemiskinan pada tahun 1998 menjadi tingkat kemiskinan yang paling tinggi. Kegagalan diatas tidak lepas dari kondisi internal fundamental ekonomi Indonesia sangat lemah, yaitu adanya kesalahan strategi dalam aplikasi pembangunana nasional.

Adanya krisis tahun 1998 mengakibatkan kenaikan harga benar-benar akan langsung berdampak kepada masyarakat miskin atau kelompok menengah ke bawah. Hal ini senada tahun 2008 
yang sebenarnya bermula pada krisis ekonomi Amerika Serikat yang lalu menyebar ke negara- negara lain seluruh dunia, termasuk Indonesia. Krisis ekonomi Amerika diawali karena adanya dorongan untuk konsumsi (Propencity to Consume). Rakyat Amerika hidup dalam konsumerisme di luar batas kemampuan pendapatan yang diterima. Sebagian besar dari masyarakat hidup dalam hutang, belanja dengan kartu kredit, dan kredit perumahan.

Akibatnya lembaga keuangan yang memberikan kredit tersebut bangkrut karena kehilangan likuiditasnya, karena piutang perusahaan kepada para kreditor perumahan telah digadaikan kepada lembaga pemberi pinjaman. Pada akhirnya perusahaan perusahaan tersebut harus bangkrut karena tidak dapat membayar seluruh hutang-hutang yang jatuh tempo pada saat yang bersamaan. Hal ini yang berakibat jatuhnya nilai mata uang kita. Aliran dana asing yang tadinya akan digunakan untuk pembangunan ekonomi dan untuk menjalankan perusahaan-perusahaan hilang, banyak perusahaan menjadi tidak berdaya, yang pada ujungnya negaralah yang harus menanggung hutang perbankan dan perusahaan swasta. Dampak lainnya adalah karena krisis global, kini semakin banyak perusahaan yang mengurangi jumlah tenaga kerjanya.

Bertambahnya angka pengangguran menyebabkan pendapatan per kapita akan berkurang serta meningkatknya angka kemiskinan. Karena krisis yang terjadi adalah krisis global, maka tenaga kerja kita yang ada di luar negeri juga merasakan imbasnya. Misalnya, harga angkutan transportasi dan sembilan kebutuhan pokok akan naik dan bakal mengurangi daya beli masyarakat miskin. Selain berdampak pada masyarakat menengah ke bawah kenaikan harga dapat juga menghambat pada pertumbuhan ekonomi bila terjadi lonjakan angka inflasi. Contohnya kenaikan BBM, sangat berpengaruh bagi seluruh masyarakat khususnya bagi para buruh. Jika harga BBM dinaikkan, APBN akan kuat, lewat pendapatan negara yang besar dan pertumbuhan ekonomi yang sehat. Namun hal ini tidak berarti jika masyarakat Indonesia masih berada dalam garis kemiskinanan. Selain akan timbulnya pengangguran yang semakin meningkat, masyarakat tidak akan mendapatkan pelayanan sosial yang baik, jaminan sosial berkualitas, rakyat tidak 
akan mendapatkan akses pendidikan yang murah dan berkualitas serta proteksi terhadap sandang - pangan - papan yang memadai.

Adanya kenaikan harga yang terus menerus tanpa diimbangi dengan penghasilan masyarakat yang naik, maka dapat di pastikan Negara Indonesia semakin terpuruk. Akibatnya banyak kebutuhan masyarakat yang tidak dapat terpenuhi, sehingga akan banyak hal yang harus terpenuhi melaui jalan kredit. Banyaknya kebutuhan masyarakat yang harus dipenuhi akan menyebabkan timbulnya peluang bagi dunia perbankan dalam penawaran kredit yang mudah didapat untuk memenuhi kebutuhan. Misalnya untuk mobilitas tinggi dalam hal pekerjaan berpindah dari tempat ketempat lain dalam waktu cepat atau meningkatnya kredit UMKM. Di tengah keterbatasan transportasi publik, sepeda motor misalnya sudah menjadi hal yang sangat penting untuk aktifitas ekonomi. Ditengah upaya memerangi kemiskinan, peranan perbankan dinilai sangat penting dan strategis. Hal ini senada dengan visi dan misi keuangan inklutif dalam mewujudkan sistem keuangan yang dapat diakses oleh seluruh lapisan masyarakat untuk mendorong pertumbuhan ekonomi, penanggulangan kemiskinan, pemerataan pendapatan dan terciptanya stabilitas keuangan di Indonesia.

Pembangunan ekonomi membutuhkan sektor perbankan sebagai motor penggerak kegiatan keuangan insklusif, meningatkan perbankan Indonesia memiliki share kegiatan keuangan sampai dengan $80 \%$. Namun demikian keterlibatan dalam keuangan inklusif tidak hanya terkait dengan tugas Bank Indonesia, namun juga Pemerintah dalam upaya pelayanan keuangan pada masyarakat luas dengan tujuan strategi pembangunan nasional untuk mendorong pertumbuhan ekonomi melalui pemerataan pendapatan, pengentasan kemiskinan serta stabilitas sistem keuangan (Bank Indonesia, 2014). Kemiskinan apabila dipandang dari sisi ekonomi muncul karena adanya ketimpangan pada kepemilikan sumber daya yang menimbulkan distribusi pendapatan yang berbeda, perbedaan dalam kualitas sumber daya manusia dan perbedaan akses dalam modal serta rendah kesempatan kerja yang ada. Tingginya tingkat kemiskinan menjadi sebuah indikator bahwa masyarakat belum berperan menjadi subjek dalam ketabilan sistem keuangan. Guna mencapai kestabilan sistem keuangan 
maka rakyat harus memiliki modal dan mental dalam membangun perekonomian salah satunya melalui UMKM yang terbukti mampu menyelamatkan perekonomian dimasa krisis.

Tabel. 3

Jumlah Debitur Biro Informasi Kredit 2011-2016

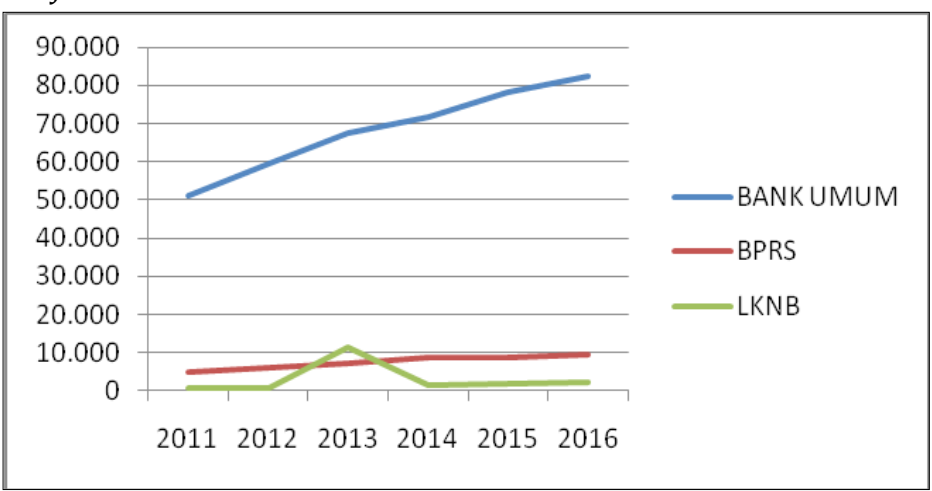

Sumber: Data Kemenkeu diolah 2017

Adanya pemberian kredit kepada UMKM dengan tujuan penyerapan tenaga kerja dan meningkatkan pendapatan dan kepercayaan rumah tangga. Sehingga ada keuntungan yang didapat per kapita yang kuat dapat menjaga kestabilan perekonomian. Keuntungan per kapita yang kuat serta berbagai langkah pemerintah yang semakin efisien dan ditargetkan dengan baik telah menjadi langkah yang sangat penting dalam mengurangi angka kemiskinan. Dari keseluruhan permasalahan diatas peneliti ingin membahas tentang mejaga stabilan sistem keuangan pada sektor rumah tangga. Dimana sektor rumah tangga ikut berperan dalam menjaga ksetabilan sistem keuangan.

Berdasar latar belakang di atas maka peneliti ingin meneliti tentang pengaruh sektor rumah tangga dalam menjaga kestabilan sistem keuangan dan untuk itu peneliti ingin membahas seberapa besar pengaruh sektor rumah tangga dalam kesetabilan sitem keuangan. Untuk itu peneliti mengambil permasalahan dalam penelitian ini "Tantangan sektor Rumah Tangga dalam menjaga Kestabilan Sektor Keuangan" 


\section{B. Kajian Pustaka}

\section{Inflasi}

Inflasi merupakan kondisi dimana terjadi kecenderungan kenaikan harga barang dan jasa secara umum dan terus menerus. Dewasa ini kecenderungan gejala inflasi sulit dihindari terutama bagi negara - negara berkembang termasuk Indonesia. Inflasi terjadi apabila tingkat harga - harga dan biaya - biaya umum naik; harga beras, bahan bakar, mobil naik; tingkat upah, harga tanah, sewa barang barang modal juga naik (Samuelsen, 1994: 296). Inflasi disebabkan oleh banyak faktor dan latar belakang. Adanya kenaikan permintaan agregat (agregat demand) yang lebih besar dibandingkan dengan penawaran agregat (agregat supply) dapat memicu terjadi inflasi. Kondisi demikian sering disebut dengan output gap. Hal ini dapat terjadi pada saat alokasi sumber daya mencapai titik optimum dan tidak dapat ditingkatkan lagi. Semakin besar output gap berarti semakin besar pula tekanan inflasi.

Faktor lain yang turut menyebabkan terjadinya inflasi dilihat dari sisi penawaran adalah adanya kenaikan biaya produksi dan ketidaklancaran sistem distribusi barang dan jasa. Kenaikan biaya produksi dan ketidaklancaran sistem distribusi akan mempengaruhi jumlah penawaran yang berkurang. Ekspektasi pelaku ekonomi yang cukup tinggi terkait dengan perkiraan di masa yang akan datang berdasarkan kebijakan pemerintah dan otoritas moneter turut memicu terjadinya inflasi.

Pada umumnya, inflasi yang terjadi di suatu negara dibedakan menjadi dua, yaitu:

a. Inflasi inti (Core Inflation) merupakan inflasi yang banyak dipengaruhi oleh faktor fundamental, seperti interaksi permintaan dan penawaran, perubahan nilai tukar, serta harga komoditi ekport import.

b. Inflasi non inti (Noise Inflation) merupakan inflasi yang disebabkan oleh faktor non fundamental, baik itu tekanan dalam kelompok barang tertentu terutama sektor pangan maupun disebabkan karena adanya perubahan kebijakan yang dilakukan oleh pemerintah. 
Sebagai salah satu persoalan ekonomi makro yang krusial, inflasi membutuhkan deteksi sedini mungkin. Terdapat beberapa indikator yang umum digunakan dalam mengukur tingkat inflasi yaitu indeks harga konsumen (IHK), indeks harga perdagangan besar (IHPB), dan deflator produk domestik bruto (PDB). IHK menggambarkan perubahan harga yang terjadi pada kelompok barang dan jasa yang umum dikonsumsi oleh masyarakat. Indonesia mengelompokkan pengeluaran berdasarkan klasifikasi konsumsi individu berdasar tujuan (the Classification of individual consumption by purpose - COICOP), yaitu :
a. Kelompok Bahan Makanan
b. Kelompok Makanan Jadi, Minuman, dan Tembakau
c. Kelompok Perumahan
d. Kelompok Sandang
e. Kelompok Kesehatan
f. Kelompok Pendidikan dan Olah Raga
g. Kelompok Transportasi dan Komunikasi (BPS, 2017)

Inflasi dapat pula diukur berdasarkan IHPB dan deflator produk domestik bruto. IHPB mengukur perubahan harga pada komoditas perdagangan besar yang terjadi antara pedagang besar. Sedangkan deflator PDB menggambarkan pengukuran level harga barang akhir (final goods) dan jasa yang diproduksi di dalam suatu ekonomi. Deflator PDB dihasilkan dengan membagi PDB atas dasar harga nominal dengan PDB atas dasar harga konstan.

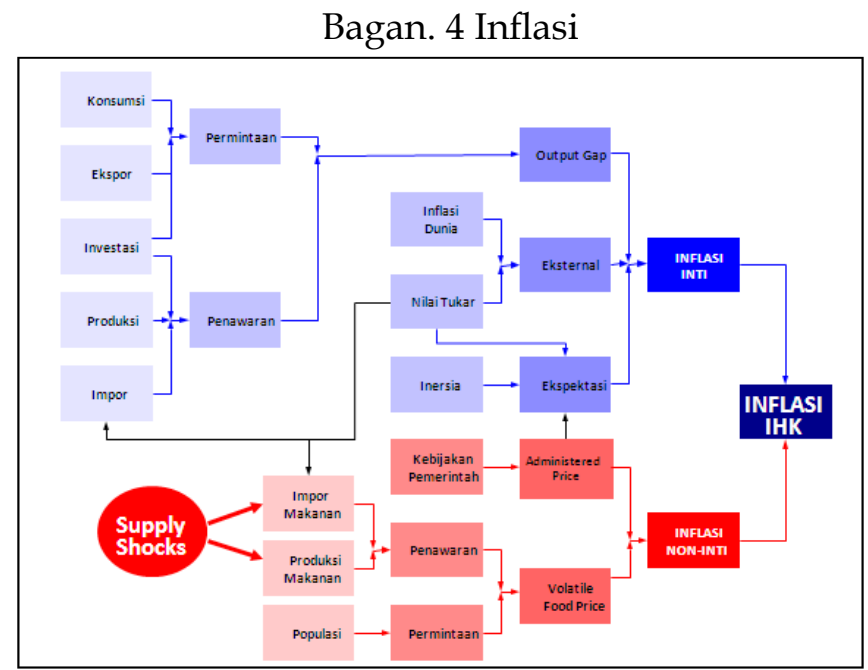


Berdasarkan tingkatannya, inflasi digolongkan menjadi inflasi ringan, inflasi sedang, inflasi berat dan hyperinflation. Dikatakan inflasi ringan jika laju inflasi mencapai maksimum 10\%. Laju inflasi berkisar antara $10-30 \%$ dikategorikan sebagai inflasi sedang. Inflasi dikategorikan inflasi berat jika laju inflasi antara $30-100 \%$ dan masuk dalam kategori hyperinflation jika laju inflasi mencapai lebih dari $100 \%$. Semakin besar laju inflasi akan menyebabkan semakin sulit inflasi diatasi. Pemerintah dalam hal ini pemegang otoritas moneter akan berusaha untuk menekan dan mengtasi inflasi dengan berbagai kebijakan moneter yang di tempuh.

Dalam rangka mengatasi inflasi dalam kerangka menciptakan stabilitas moneter, BI menerapkan kebijakan inflation targeting framework. Inflation targeting framework merupakan suatu kerangka kerja kebijakan moneter yang bercirikan adanya penyataan resmi bank sentral dan dikuatkkan dengan UU bahwa tujuan akhir kebijakan tersebut mencapai dan menjaga tingkat inflasi rendah serta adanya pengumuman target inflasi kepada publik. Kebijakan moneter open market, cash ratio dan politik diskonto sering dimanfaatkan pemerintah untuk mengatasi inflasi. Kebijakan open market merupakan kebijakan pemerintah untuk menjual atau membeli surat berharga. Kebijakan cash ratio merupakan kebijakan yang ditempuh dengan mengubah besar cadangan wajib minimum. Politik diskonto ditempuh dengan menaikkan dan menurunkan tingkat suku bunga.

\section{Kemiskinan}

Masalah kemiskinan mengalami perkembangan tidak hanya permasalahan ekonomi semata termasuk juga permasahan sosial. kemiskinan menurut BPS dipandang sebagai ketidakmampuan dari sisi ekonomi untuk memenuhi kebutuhan dasar makanan dan bukan makanan yang diukur dari sisi pengeluaran. Sedangkan menurut UNDP kemiskinan adalah ketidakmampuan untuk memperluas pilihan hidup antara lain dengan memasukkan penilaian tidak adanya partisipasi dalam pegambilan kebijakan publik sebagai salah satu indikator kemiskinan. Kemiskinan yang dialami masyarakat sangat beragam kondisi dan tingkatannya. Dalam rangka mengukur 
kemiskinan, BPS menggunakan konsep kemampuan memenuhi kebutuhan dasar (basic needs approach). Dengan pendekatan ini, kemiskinan dipandang sebagai ketidakmampuan dari sisi ekonomi untuk memenuhi kebutuhan dasar makanan dan bukan makanan yang diukur dari sisi pengeluaran.

Penduduk yang memiliki rata-rata pengeluaran perkapita per bulan dibawah garis kemiskinan dikategorikan sebagai penduduk miskin. Penduduk miskin tersebar tidak hanya di daerah perkotaan melainkan juga wilayah pedesaan. Sedangkan garis kemiskinan (GK) yang dijadikan sebagai indikator merupakan penjumlahan dari Garis Kemiskinan Makanan (GKM) dan Garis Kemiskinan Non Makanan (GKNM). Menurut BPS (2016) Garis Kemiskinan Makanan (GKM) merupakan nilai pengeluaran kebutuhan minimum makanan yang disetarakan dengan 2100 kilo kalori perkapita perhari. Paket komoditi kebutuhan dasar makanan diwakili oleh 52 jenis komoditi (padi-padian, umbi-umbian, ikan, daging, telur dan susu, sayuran, kacang-kacangan, buah-buahan, minyak dan lemak, dll). Garis Kemiskinan Non Makanan (GKNM) adalah kebutuhan minimum untuk perumahan, sandang, pendidikan dan kesehatan. Paket komoditi kebutuhan dasar non makanan diwakili oleh 51 jenis komoditi di perkotaan dan 47 jenis komoditi di pedesaan.

Kemiskinan yang terjadi pada suatu kelompok masyarakat disebabkan oleh banyak faktor baik faktor intern maupun faktor ekstern. Baswir (2004:26) membagi kemiskinan berdasarkan penyebabnya meliputi kemiskinan natural, kemiskinan kultural, dan kemiskinan strukural. Kemiskinan natural marupakan kemiskinan yang bersifat alamiah karena adanya keterbatasan individu sebagai akibat adanya keterbatasan kepemilikan sumber daya alam dan sumber daya manusia. Kemiskinan ini terutama banyak dialami oleh masyarakat terutama di wilayah minim kekayaan sumber saya alam. Kemiskinan kultural merupakan kemiskinan yang terjadi karena adanya pelestarian kemiskinan dalam suatu masyarakat. Sedangkan kemiskinan strukural merupakan kemiskinan yang terjadi karena adanya perubahan struktur ekonomi, sosial di masyarakat.

Kuncoro (2003: 107) mejelakan penyebab kemiskinan dilihat dari sudut pandang ekonomi meliputi: (1). Kemiskinan 
muncul karena ketidaksamaan kepemilikan sumber daya yang menimbulkan distribusi pendapatan yang timpang, (2). Kemiskinan muncul akibat perbedaan kualitas sumber daya manusia, (3). Kemiskinan muncul akibat perbedaan akses modal. Kemiskinan menjadi persoalan ekonomi dan sosial utama yang membutuhkan penyelesaian segera. Sebelum penyelesaian, perlu dilakukan pengukuran tingkat kemiskinan agar dapat diketahui metode atau solusi yang tepat menghadapi masalah kemiskinan tersebut.

Menurut Hamid (2006: 93) menjelaskan ukuran kemiskinan menjadi dua yaitu kemiskinan absolut dan relatif. Kemiskinan absolut memberi indikator mengenai keadaan perekonomian suatu daerah yang sebagian penduduknya mendapatkan nafkah yang hanya dapat dipakai untuk memenuhi taraf kehidupan minimum. Sedangkan konsep kemiskinan relatif di dasarkan pada tingkat kesepadanan pendapatan dengan lingkunga.

Tingkat kemiskinan masih menjadi indikator utama untuk menilai tingkat kemiskinan negara. Menurut Tambunan (2012: 151), terdapat dua hal lain yang perlu diperhatikan untuk menganalisis kemiskinan di Indonesia yaitu kedalaman dan keparahan kemiskinan. Kedalaman kemiskinan lebih menunjukkan pada rata rata esenjangan pengeluaran penduduk miskin terhadap batas miskin yang diukur dengan poverty gap index. Sedangkan keparahan kemiskinan menunjukkan ketimpangan pengeluaran dari penduduk paling miskin dari garis kemiskinan yang diukur dengan poverty severity index.

Kimiskinan dilihat dari sudut pandang makro dapat dilihat dari besarnya gap/kesenjangan pada distribusi pendapatan nasional. Kesenjangan distribusi pendapatan nasional dapat dilihat dari besarnya koefisien gini yang ditunjukkan melalui kurve Lorenz. Koefisien Gini (Gini Ratio) merupakan ukuran ketimpangan agregat (secara keseluruhan) yang angkanya berkisar antara nol (pemerataan sempurna) hingga satu (ketimpangan yang sempurna). Semakin besar angka koefisien gini yang di dapatkan menunjukkan distribusi pendapatan makin timpang, demikian pula sebaliknya. Koefisien Gini diperoleh dengan menghitung rasio bidang yang terletak antara garis diagonal dan kurva Lorenz dibagi dengan luas separuh bidang di mana kurva Lorenz itu berada 


\section{Kredit}

Dewasa ini, fenomena kredit menjadi hal yang umum di tengah - tengah masyarakat. Kredit dilihat dari segi bahasa berasal dari kata " kredit" yang berasal dari bahasa Yunani " credere" yang berarti kepercayaan akan kebenaran dalam praktik sehari - hari . "Kredit adalah kemampuan untuk melaksanakan suatu pembelian atau mengadakan suatu pinjaman dengan suatu janji, pembayaran akan dilaksanakan pada jangka waktu yang telah disepakati “. (Astiko, 1996:5).

Menurut Undang - undang no 10 tahun 1998 tentang perbankan, menjalaskan kredit merupakan penyediaan uang tagihan atau yang dapat dipersamakan dengan itu, berdasarkan persetujuan atau kesepakatan pinjaman antara bank dan pihak lain yang mewajibkan pihak peminjam untuk melunasi utangnya setelah jangka waktu tertentu dengan jumlah bunga, imbalan atau pembagian hasil keuntungan.

Guna menghasilkan sistem kredit yang sehat dan terkontrol, harus dipenuhi persyaratan kredit yang dikenal dengan 6C, yang terdiri dari character, capacity, capital, collateral, condition of economy dan constrain. Character menunjukan sifat dan kepribadian yang dimiliki oleh calon debitur. Character penting untuk melihat itikad baik calon debitur untuk membayar angsuran dan melunasi pinjaman (willingness to pay) sesuai dengan jatuh tempo. Capacity menunjukkan kemampuan calon debitur untuk melunasi pinjaman tepat pada waktunya dengan mempertimbangan berbagai aspek salah satunya aspek finansial. Capital menggambarkan banyaknya modal yang dimiliki oleh calon nasabah. Besar modal sangat mempengaruhi besar kecilnya kredit yang akan disetujui. Collateral meupakan jaminan yang diberikan oleh calon debitur. Pada umumnya jaminan adalah berupa benda namun saat ini jaminan dapat berupa surat berharga maupun jaminan pribadi atau avails. Condition of economy mengindikasikan keadaan ekonomi saat ini. Constrain adalah batasan dan hambatan yang tidak memungkinkan suatu bisnis untuk dilaksanakan pada tempat tertentu.

Dilihat berdasarkan fungsinya kredit dibedakan menjadi kredit produktif dan kredit konsumtif. Kredit produktif merupakan 
kredit yang diarahkan pada peningkatan modal kerja yang di harapkan mampu merangsang peningkatan produktivitas. Sedangkan kredit konsumtif lebih mengarah pada kredit sektor rumah tangga dalam rangka pemenuhan modal kerja.

\section{Stabilitas Sistem Keuangan}

Sistem keuangan merupakan salah satu komponen makro yang mempengaruhi stabilitas perekonomian suatu negara. Menurut BI (2014:174) menjelaskan bhawa sistem keuangan adalah sistem yang memungkinkan terjadinya transfer keuangan antara pihak yang kelebihan dana dengan pihak yang kekurangan dana. Berdasarkan prinsip operasionalnya sistem keuangan dapat berdasar prinsip konvensional maupun berdasar prinsip syariah. Sedangkan dilihat dari bentuknya sistem keuangan di dunia dikenal dengan dengan bank-based industry (sistem keuangan yang didomiinasi peran dan pasar perbankan) dan market- based industry (sistem keuangan yang didomiinasi peran dan pasar sektor pasar modal).

Sistem keuangan memiliki fungsi yang utama dalam memperlancar arus dana baik berupa tabungan atau deposito; pendanaan bagi sektor rumah tangga, perusahaan maupun pemerintah; investasi; pertumbuhan ekonomi dan pengeluaran pemerintah. Mengingat perannya yang penting, sistem keuangan harus diatur dan dijaga oleh pihak otoritas baik oleh BI, OJK mapun LPS. Pengaturan dan pengawasan dilakukan terhadap pengawasan secara makro (macroprudential surveillance), pengawasan secara mikroindividual (microprudential surveillance), perlindungan konsumen dan kebijkan persaingan pasar.

Menurut Scinasi (2004) dalam BI (2014) mendefinisikan stabilitas sistem keuangan sebagai kemampuan sistem keuanagan untuk melakukan alaokasi sumber dana dalam mendukung kegiatan ekonomi, mengelola resiko dan bertahan dari gejolak. Sistem keuangan yang stabil mampu mengalokasikan sumber dana dan menyerap kejutan (shock) yang terjadi sehingga dapat mencegah gangguan terhadap kegiatan sektor riil dan sistem keuangan. Dengan demikian sistem keuangan yang stabil dapat 
menjalankan fngsi intermediasi, pembayaran, pengelolaan resioko sehingga dapat mendukung pertubuhan ekonomi nasional.

Sistem keuangan masuk tahap tidak stabil, saat sistem tersebut telah membahayakan dan menghambat kegiatan ekonomi. Apabila sistem keuangan tidak stabil dan tidak berfungsi secara efisien, pengalokasian dana tidak akan berjalan dengan baik sehingga dapat menghambat pertumbuhan ekonomi. Ketidakstabilan sistem keuangan dapat dipicu oleh berbagai macam penyebab dan gejolak yang pada umumnya merupakan kombinasi antara kegagalan pasar, baik karena faktor struktural maupun perilaku. Kegagalan pasar itu sendiri dapat bersumber dari eksternal (internasional) dan internal (domestik). Risiko yang sering menyertai kegiatan dalam sistem keuangan antara lain risiko kredit, risiko likuiditas, risiko pasar dan risiko operasional.

Perkembangan globalisasi sektor finansial dan inovasi produk keuangan yang semakin dinamis dapat mengakibatkan meningkat dan beragamnya sumber-sumber pemicu ketidakstabilan sistem keuangan. Identifikasi sumber ketidakstabilan sistem keuangan umumnya lebih bersifat forward looking (melihat kedepan) guna mengetahui potensi risiko yang akan timbul dan mempengaruhi kondisi sistem keuangan mendatang.

Secara umum ketidakstabilan sistem keuangan dapat mengakibatkan dampak negatif seperti: transmisi kebijakan moneter tidak berfungsi secara normal, fungsi intermediasi tidak dapat berjalan maksimal, munculnya ketidakpercayaan publik terhadap sistem keuangan mendorong timbulnya bank panic. Dengan demikian upaya untuk menjaga kestabilan sistem keuangan dalam rangka menjaga kestabilan perekonomian wajib dilakukan. Menurut BI kestabilan sistem keuangan sangat dipengaruhi oleh faktor endogen dan eksogen. 
Tabel. 5

Sumber Resiko Ketidakstabilan Sistem Keuangan

\begin{tabular}{|l|l|}
\hline \multicolumn{2}{|c|}{ Sumber Resiko Ketidakstabilan Sistem Keuangan } \\
\hline \multicolumn{1}{|c|}{ Faktor Endogen } & \multicolumn{1}{c|}{ Faktor Eksogen } \\
\hline Institusi: & $\begin{array}{l}\text { Gangguan ekonomi makro } \\
\text { - Risiko finansial }\end{array}$ \\
- Risiko operasional & $\begin{array}{l}\text { - Ketidakseimbangan } \\
\text { - Rebijakan } \\
\text { - Risiko hukum }\end{array}$ \\
- Risiko reputasi & - Resiko ekonomi lingkungan \\
- Risiko konsentrasi & Resiko tak terhindarkan: \\
- Risiko capital & - Bencana alam \\
Pasar: & - Kekacauan politik / sosial \\
- Risiko counterpart & Kegagalan usaha \\
- Harga asset yang tidak tepat & \\
- Pengambilan dana besar besaran & \\
- Efek menular & \\
Infrastruktur: & \\
- Risiko sistem pembayaran / & \\
- Ketlement & \\
- Kelemahan hukum / peraturan & \\
- Kelemahan sistem akuntansi & \\
- Runtuhnya kepercayaan \\
Efek domino
\end{tabular}

BI Rate merupakan kebijakan Bank Indoneian sebagai otoritas moneter terkait suku bunga kebijakan yang diumumkan kepada publik. BI Rate setiap bulannya diumumkan oleh Dewan Gubernur Bank Indonesia pada Rapat Dewan Gubernur bulanan serta diimplementasikan pada setiap operasi moneter. Pengelolaan likuiditas (liquidity management) di pasar uang guna mencapai sasaran operasional kebijakan moneter yang dicerminkan pada perkembangan suku bunga Pasar Uang Antar Bank Overnight (PUAB O/N). Pergerakan suku bunga PUAB ini diharapkan akan diikuti oleh perkembangan suku bunga deposito, dan pada pada akhirnya berpengaruh pada suku bunga kredit perbankan. BI rate menjadi salah satu indikator unttuk menjaga stabiliatas keuangan. Dengan mempertimbangkan pula faktor-faktor lain dalam perekonomian, Bank Indonesia pada umumnya akan menaikkan BI Rate apabila inflasi ke depan diperkirakan melampaui sasaran yang 
telah ditetapkan, sebaliknya Bank Indonesia akan menurunkan BI Rate apabila inflasi ke depan diperkirakan berada di bawah sasaran yang telah ditetapkan.

\section{Metodologi}

Berdasarkan tujuan penelitian yang telah ditetapkan, maka penelitian ini menggunakan menggunakan desain penelitian kuantitatif. Ruang lingkup penelitian ini adalah negara Indonesia dengan rentang waktu tahun selama 9 tahun yaitu periode 20072015. Proses analisis data dilakukan berdasarkan model uji regresi OLS.Inflasi, kemiskinan dan kredit bertindak sebagai variabel independen. Sedangkan stabilitas sistem keuangan sebagai variabel dependennya dengan indikator BI Rate. Data BI Rate dan laju inflasi di peroleh dari annual report Bank Indonesia. Sedangkan data kemiskinan dan timgkat kredit diperoleh dari Badan Pusat Statistik dari situs resmi Badan Pusat Satistik

\section{Analisis}

Pengaruh Inflasi (X1), Kemiskinan (X2) dan Kredit (Y) terhadap kestabiltas sistem keuangan dapat dilihat dengan menggunakan analisi regresi linier berganda dengan persamaan sebagai berikut:

Stabilitas sistem keuangan $(\mathrm{Y})=\beta_{0}+\beta_{1 \text { Inflasi }}+\beta_{2 \text { kemiskinan }}+\beta_{3 \text { kredit }}+\mathrm{e}$

$\begin{array}{lll}\text { Dimana : } & Y & =\text { BI Rate } \\ \beta_{0} & =\text { Konstanta } \\ \beta_{1} \beta_{2} & =\text { Koefisien Regresi } \\ \mathrm{e} & =\text { Error }\end{array}$


Hasil pengolahan analisis regresi berganda dengan menggunakan software Eviews 8.0 adalah sebagai berikut:

Tabel. 6

Analisis Regresi Berganda

Dependent Variable: BIRATE

Method: Least Squares

Date: 09/22/16 Time: 21:02

Sample: 20072015

Included observations: 9

\begin{tabular}{ccccc}
\hline \hline Variable & Coefficient & Std. Error & t-Statistic & Prob. \\
C & 23.94512 & 8.693158 & 2.754479 & 0.0401 \\
INFLASI & 0.087104 & 0.109786 & 0.793397 & 0.4635 \\
KEMISKINAN & -48.70105 & 24.06770 & -2.023502 & 0.0989 \\
KREDIT & $9.06 \mathrm{E}-07$ & $5.94 \mathrm{E}-07$ & 1.525779 & 0.1876 \\
\hline \hline R-squared & 0.629900 & Mean dependent var & 7.325556 \\
Adjusted R-squared & 0.407840 & S.D. dependent var & 0.994775 \\
S.E. of regression & 0.765499 & Akaike info criterion & 2.604525 \\
Sum squared resid & 2.929944 & Schwarz criterion & 2.692180 \\
Log likelihood & -7.720361 & Hannan-Quinn criter. & 2.415365 \\
F-statistic & 2.836618 & Durbin-Watson stat & 2.312539 \\
Prob(F-statistic) & 0.145398 & & \\
\hline \hline
\end{tabular}

Berdasarkan perhitungan Eviews tersebut diperoleh persamaan regresi linier berganda sebagai berikut:

Kestabilan sitem Keuangan $(Y)=23,9+0,087$ (Inflas) $i$ 48,70(Kemiskinana) + 9,06(kredit)

Dari persamaan regresi linier berganda diatas diperoleh nilai konstanta sebesar 23,9. Artinya, jika variabel kestabilan sistem keuangan ( $\mathrm{Y}$ ) dipengaruhi ketiga variabel bebasnya atau inflasi (X1), Kemiskinan (X2) dan Kredit (X3) bernilai nol, maka besarnya ratata kestabilan sistem keuangan akan bernilai $23,9 \%$.

Nilai koefisien regresi untuk variabel-variabel bebasnya menggambarkan apabila diperkirakan variabel bebasnya naik sebesar 1 unit dan nilai variabel bebas lainnya di perkirakan konstan atau sam dengan nol, maka nilai variabel terikat diperkirakan bisa naik atau bisa turun sesuai dengan tanda koefisien regresi variabel bebasnya.

Koefisen regresi untuk variabel bebas X1 (inflasi) bernilai positif, menunjukkan adanya hubungan yang serah antara inflasi 
(X1) dengan kestabilan sistem ekonomi (Y). Koefisien regresi variabel X1 sebesar 0,087 mengandung arti untuk setiap penambahan regresi variabel $\mathrm{X} 1$ sebesar satu satuan akan menyebabkan meningkatnya BI Rate (Y) sebesar 0,087.

Koefisien regresi untuk variabel X2 (kemiskinan) bernilai negatif menunjukkan hubungan yang berlawanan arah antara kestabilan sistem keuangan ( $\mathrm{Y}$ ). Koefisien regresi $\mathrm{X} 2$ sebesar $-48,70$ mengandung arti untuk setiapa penambahan kemiskinan (X2) makan sebesar satu satuan akan menyebabkan penurunanan BI Rate( Y) sebesar 48,70.

Koefisien regresi untuk variabel X3 (kedit) bernilai positif menunjukkan hubungan yang searah antara BI rate $(\mathrm{Y})$. Koefisien regresi X3 sebesar 9,06 mengandung arti untuk setiap pemnambahan satu satuan variabel X3 akan menyebabkan meningkatnya BI Rate (Y) sebesar 9,06.

\section{Pengujian Hipotesis}

Selanjutnya untuk menguji apakah infalsi, kemiskinan dan kredit berpengaruh terhadap Kestabilitasan Sistem Keuangan signifikan baik secara bersama-sama (simultan) maupun parsial (individual), dilakukan uji signifikanasi. Pengunian dimulai dari pengujian simultan, dan apabila hasil pengujian simultan di lanjutkan dengan uji parsial.

\section{Pengujian hipotesis secara simultan}

Untuk mengetahui signifan pengaruh variabel-variabel bebas secara bersama-sama atas suatu variabel terikat digunakan uji F. Hasil pengujian hipotesis secara simultan menggunakan eviews 8.0. berdasarkan tabel 4.1 dapat diketahui bahwa F-hitung sebesar 2.836618. Adapun nilai F-tabel pada tingkat signifikan 5\% degree of fredom (df) sebesar 3,86. Jika kedua nilai ini dibandingkan maka nilai $\mathrm{F}$ hitung lebih kecil dari F tabel $(2,836<3,86)$. Sehingga H0 di terima. Dengan demikian dapat dsimpulkan bahwa secara simultan variabel independent (inflasi, kemiskinan dan kredit) tidak memiliki pengaruh yang sangat signifikan terhadap variabel dependent (kestabilan sistem keuangan). 


\section{Pengujian Hipotesis Secara Parsial}

Untuk mengetahui variabel yang berpengaruh signifikan secara parsial dilakukan pengujian koefisien regresi dengan menggunakan statistik Uji t. Penentuan hasil pengujian (penerima/ penolakan H0) dapat dilakukan dengan membandingkan t-hitung dengan $\mathrm{t}$ tabel atau juga dapat dilihat dengan membandingkan dari nilai signifikansinya. Hasil pengumjian hipotesis secara parsial dapat menggunakan eviews 8.0.

Berdasarkan out pada tabel 4.1 dapat dilihat nilai t-tabel yang diperoleh setiap variabel. Untuk membuat kesimpulan menerima atau menolak $\mathrm{H} 0$, terlebih dahulu harus ditentukan nilai-nilai t-tabel yang akan digunakan. Niali ini tergantung pada besarnya degree of freedom (df) dan tingkat signifikansi yang digunakan. Dengan menggunakan tingkat signifikansi $10 \%$ dan nilai df sebesar n-k-1 (9-3-1=5) di peroleh nilai t-tabel sebesar 2,015

Hasil pengujian pengarug setiap variabel independent (inflasi, kemiskinan dan kredit) terhadap variabel dependent (kestabilan sistem keuangan) di Indonesia selama 2007-2015 adalah sebagai berikut:

\section{a. Pengaruh Inflasi terhadap Kestabilan Sistem Keuangan}

Berdasarkan ouput diketahui t-hitung sebesar 0.793397. jika sebandingkan dengan nilai t-tabel sebesar 2,015 maka t-hitung yang diperoleh lebih kecil dari t-tabel. Sehingga HO di terima. Dengan demikian dapat disimpulkan bahwa variabel inflasi tidak berpengaruh secara signifikan terhadap kestabilan sistem keuangan.

Peningkatan inflasi tidak menggambarkan peningkatan kestabilan sistem keuangan, hal ini menunjukkan bahwa peningkat inflasi todak selalu diikuti dengan kestabilan sitem keuangan.

b. Pengaruh Kemiskinan terhadap Kestabilan Sistem Keuangan

Berdasarkan ouput diketahui nilai t-hitung sebesar 2.023. Jika dibandingkan dengan nilai t-tabel sebesar 2,015 maka t-hitung yang diperoleh lebih besar dari t-tabel. Sehingga H0 ditolak. Dengan demikian dapat disimpulkan bahwa variabel kemiskinan 
berpengaruh terhadap kestabilan sistem keuangan. Sehingga jika tingkat kemiskinan turun maka kestabilan sitem keuangan akan mendekati stabil.

\section{c. Pengaruh Kredit terhadap Kestabilan Sistem Keuangan}

Berdasarkan ouput diketahui nilai t-hitung sebesar 1.525779. Jika dibandingkan dengan nilai t-tabel sebesar 2,015 maka t-hitung yang diperoleh lebih kecil dari t-tabel. Sehingga H0 diterima. Dengan demikian dapat disimpulkan bahwa variabel kredit tidak berpengaruh terhadap kestabilan sistem keuangan.

\section{d. Koefiensien Determinasi}

Koefisien determinasi pada intinya mengukur seberapa jauh kemampuan model dalam menerangkan variasi variabel. Koefisien determinasi ini digunakan karena dapat menjelaskan kebaikan dari model regresi dalam variabel dependen. Semakin tinggi nilai koefisiens determinasi maka akan semakin baik pula kemampuan variabel independen dalam menjelaskan variaben dependen. Nilai koefisien determinasi adalah antara nol dan satu. Nialai $\mathrm{R}^{2}$ yang kecil bearti kemampuan variabel-variabel indepensen dalam menjelaskan variasi variabel amat terbatas. Nilai yang mendekati satu bearti variabel-variabek independen memberikan hampir semua informasi yang dibutuhkan untuk memprediksi variasi dependen.

Dari hasil output Eviews 8.0 (tabel 4.1) dapat dilihat bahwa koefisien determinasi atau R Square sebesar 0.629 atau $62,9 \%$. Hal ini menunjukkan bahwa variabel yang diteliti (inflasi, kemiskian dan kredit)memberikan pengaruh terhadap kestabilan sistem keuangan sebesar $62,9 \%$, sedangkan sisanya dipengaruhi variabel yang tidak diteliti (variabel pengganggu).

\section{D.Pembahasan}

\section{Pengaruh Inflasi terhadap Kestabilan Sistem Keuangan}

Inflasi terjadi apabila tingkat harga - harga dan biaya - biaya umum naik; harga beras, bahan bakar, mobil naik; tingkat upah, harga tanah, sewa barang barang modal juga naik (Samuelsen, 1994: 296). Inflasi disebabkan oleh banyak faktor dan latar belakang. Adanya kenaikan permintaan agregat (agregat demand) yang lebih 
besar dibandingkan dengan penawaran agregat (agregat supply) dapat memicu terjadi inflasi. Kondisi demikian sering disebut dengan output gap. Hal ini dapat terjadi pada saat alokasi sumber daya mencapai titik optimum dan tidak dapat ditingkatkan lagi. Semakin besar output gap berarti semakin besar pula tekanan inflasi. Sebagai salah satu persoalan ekonomi makro yang krusial, inflasi membutuhkan deteksi sedini mungkin. Terdapat beberapa indikator yang umum digunakan dalam mengukur tingkat inflasi yaitu indeks harga konsumen (IHK), indeks harga perdagangan besar (IHPB), dan deflator produk domestik bruto (PDB). Salah satu upaya menjaga kestabilitas perekonomian adalah melalui kebijakan moneter. Misalnya dengan pertumbuhan ekonomi, menjaga stabilitas harga (inflasi), tercapainya keseimbangan neraca pembayaran dan pengurangan pengangguran (Natsir,2008).

Berdasarkan analaisis yang dilakukan inflasi merupakan salah satu faktor yang mempengaruhi kestabilitas sistem keuangan. Peningkatan inflasi berpengaruh tidak signifikan dalam kestabilan sistem keuangan hal sejalan dengan Sofri (2016) menyatakan bahawa hubungan anatara stabilitas sitem keuangan berhubungan negatif.

\section{Pengaruh Kemiskinan terhadap Kestabilan Sistem Keuangan}

Masalah kemiskinan mengalami perkembangan tidak hanya permasalahan ekonomi semata termasuk juga permasahan sosial. kemiskinan menurut BPS dipandang sebagai ketidakmampuan dari sisi ekonomi untuk memenuhi kebutuhan dasar makanan dan bukan makanan yang diukur dari sisi pengeluaran. Sedangkan menurut UNDP kemiskinan adalah ketidakmampuan untuk memperluas pilihan hidup antara lain dengan memasukkan penilaian tidak adanya partisipasi dalam pegambilan kebijakan publik sebagai salah satu indikator kemiskinan. Kemiskinan yang dialami masyarakat sangat beragam kondisi dan tingkatannya. Dalam rangka mengukur kemiskinan, BPS menggunakan konsep kemampuan memenuhi kebutuhan dasar (basic needs approach). Dengan pendekatan ini, kemiskinan dipandang sebagai ketidakmampuan dari sisi ekonomi untuk memenuhi kebutuhan dasar makanan dan bukan makanan yang diukur dari sisi pengeluaran. 
Kuncoro (2003: 107) mejelakan penyebab kemiskinan dilihat dari sudut pandang ekonomi meliputi: (1). Kemiskinan muncul karena ketidaksamaan kepemilikan sumber daya yang menimbulkan distribusi pendapatan yang timpang, (2). Kemiskinan muncul akibat perbedaan kualitas sumber daya manusia, (3). Kemiskinan muncul akibat perbedaan akses modal. Kemiskinan menjadi persoalan ekonomi dan sosial utama yang membutuhkan penyelesaian segera.

Berdasarkan hasil analisis yang telah dilakukkan menunjukkan bahwa kemiskinan berpengaruh terhadap kestabilan sistem keuangan. Hal juga sejalan dengan tujuan dari Bank Indonesia yang mengatur stabilitas keuangan secara umum dan macro terhadap perbankan nasional. Berbeda dengan perbankan umum secara nasional yang mempunyai hubungan langsung dengan usaha masyarakat mikro. Dimana Peran Intermediasi dana perbankan sangat mendukung sektor riil bagi pembangunan ekonomi yang secara langsung dapat mengentaskan kemiskinan dan kesenjangan. Salah satu upaya untuk menanggulangi kemiskinan adalah melalui pemberdayaan UMKM yang telah terbukti memiliki daya tahan yang relatif kuat dalam menghadapi krisis ekonomi yang lalu.

Salah satu upaya untuk menanggulangi kemiskinan adalah melalui pemberdayaan UMKM yang telah terbukti memiliki daya tahan yang relatif kuat dalam menghadapi krisis ekonomi yang lalu. Peran penting UMKM itu sendiri dapat ditinjau dari beberapa aspek, yaitu jumlah unit usaha yang terbentuk, penyerapan tenaga kerja, perannya dalam peningkatan produk domestik bruto (PDB) dan sumbangannya terhadap ekspor nasional. Dalam kurun waktu 1997-2001 rata-rata unit UMKM secara nasional mencapai 99,81\% dari total perusahaan yang ada. Tenaga kerja yang bekerja dalam sektor UMKM ini juga mencapai 99,48\% dari total pekerja nasional, selain itu UMKM memberikan sumbangan hingga 55,1\% kepada PDB Nasional.

\section{Pengaruh Kredit terhadap Kestabilan Sistem Keuangan}

Menurut Undang - undang no 10 tahun 1998 tentang perbankan, menjalaskan kredit merupakan penyediaan uang tagihan atau yang dapat dipersamakan dengan itu, berdasarkan 
persetujuan atau kesepakatan pinjaman antara bank dan pihak lain yang mewajibkan pihak peminjam untuk melunasi utangnya setelah jangka waktu tertentu dengan jumlah bunga, imbalan atau pembagian hasil keuntungan.

Guna menghasilkan sistem kredit yang sehat dan terkontrol, harus dipenuhi persyaratan kredit yang dikenal dengan 6C, yang terdiri dari character, capacity, capital, collateral, condition of economy dan constrain. Character menunjukan sifat dan kepribadian yang dimiliki oleh calon debitur. Character penting untuk melihat itikad baik calon debitur untuk membayar angsuran dan melunasi pinjaman (willingness to pay) sesuai dengan jatuh tempo. Capacity menunjukkan kemampuan calon debitur untuk melunasi pinjaman tepat pada waktunya dengan mempertimbangan berbagai aspek salah satunya aspek finansial. Capital menggambarkan banyaknya modal yang dimiliki oleh calon nasabah. Besar modal sangat mempengaruhi besar kecilnya kredit yang akan disetujui. Collateral meupakan jaminan yang diberikan oleh calon debitur. Pada umumnya jaminan adalah berupa benda namun saat ini jaminan dapat berupa surat berharga maupun jaminan pribadi atau avails. Condition of economy mengindikasikan keadaan ekonomi saat ini. Constrain adalah batasan dan hambatan yang tidak memungkinkan suatu bisnis untuk dilaksanakan pada tempat tertentu.

Dilihat berdasarkan fungsinya kredit dibedakan menjadi kredit produktif dan kredit konsumtif. Kredit produktif merupakan kredit yang diarahkan pada peningkatan modal kerja yang di harapkan mampu merangsang peningkatan produktivitas. Sedangkan kredit konsumtif lebih mengarah pada kredit sektor rumah tangga dalam rangka pemenuhan modal kerja.

Berdasarkan hasil analisis yang telah dilakukkan menunjukkan bahwa kredit tidak berpengaruh terhadap kestabilan sistem keuangan dikarenakan adanya kegagalan dalam sistem pembayaran, kegagalan tersebut menimbulkan resiko yang bersifat menular sehingga dapat menimbulkan gangguan yang sistemik (Fauzy, 2012). 


\section{Pengaruh Inflasi, Kemiskinana dan Kredit terhadap Kestabilan Sistem Keuangan}

Hubungan ketiga variabel independent (inflasi, kemiskinan dan kredit) secara simultan dengan stabilitas sistem keuangan menunjukkan kriteria kuat. Jadi pada permasalahan yang sedang diteliti diketahui bahwa secara simultan ketiga variabel independent/bebas (inflasi, kemiskinan dan kredit) memiliki hubungan yang kuat dengan stabilitas sistem keuangan di Indonesia selama periode 2007-2015.

Sementaara nilai dari R-Square (0.629900), menunjukkan bahwa ketiga variabel independent/bebas yang terdiri dari inflasi, kemiskinan dan kredit secara simultan memiliki pengaruh yang membuat stabilitas sistem keuangan meningkat atau menurun. Artinya secara bersama-sama variabel bebas (inflasi, kemiskinana dan kredit) memberikan kontribusi / pengaruh sebesar $62.9 \%$ terhadap kestabilitasan sistem keuangan. Sisanya merupakan pengaruh dari faktor lain diluar ketiga variabel bebas yang diteliti. Jadi besar kecil stabilitas sistem keuangan tidak hanya dipengaruhi ketiga variabel tersebut. Namun juga dapat dipengaruhi oleh variabel-variabel lainnya seperti kegagalan pasar, likuiditas, resiko pasar dan resiko operasional.

\section{E. Simpulan}

Stabilitas sistem keuangan merupakan salah satu kunci dari stabilitas ekonomi suatu negara. Stabilitas sistem keuangan mempercepat arus pendanaan dari pihak yang kelebihan dana dan pihak kekurangan dana. Sektor rumah tangga merupakan kelompok masyarakat yang rentan sekali terhadap dampak instabilitas sistem. Kerentanan ekonomi sektor rumah tangga diindikasikan adanya goncangan pada pendapatan/penghasilan RT serta ketahanannya terhadap goncangan tersebut dilihat dari sektor makro. Hal yang dirasakan sektor rumah tangga terhadap instabilitas sistem keuangan dilihat dari sektor inflasi, kemiskinan dan kredit memberikan pengaruh secara simultan

Berdasarkan hasil penelitian yang dapat direkomendasikan kepada pemerintah khususnya dalam hal ini adalah Bank Indonesia 
Daya Tahan Sektor Rumah Tangga Dalam...

adalah upaya untuk mengantisipasi dan menghilangkan kerentanan sektor rumah tangga terhadap instabilitas sistem euangan melalui berbagai kebijakan pro masyarakat bawah. Salah satu hal yang ditempuh adalah adanya edukasi masyarakat dalam memanfaatkan, mengakses layanan sistem keuangan secara bijak dan selektif. 


\section{DAFTAR PUSTAKA}

Anas, Azwar. 2006. Analisis Kebijakan Moneter Dalam Menstabilkan Inflasi dan Pengangguran di Indonesia: Skripsi Fakultas Ekonomi Institute Pertanian Bogor. Bogor.

Astiko. 1996. Manajemen Perkreditan. Andi Offset. Yogyakarta.

Baswir, Revrisond. 2004. Drama Ekonomi Idonesia. Kreasi Wacana. Yogyakarta

Bank Indonesia. 2014. Pengantar Kebanksentralan: Teori dan Praktik di Indonesia. Raja Grafindo Persada. Jakarta.

Badan Pusat Statistik. 2016. Data Kemiskinan. Jakarta

Deliarnov. 2012. Perkembangan Pemikiran Ekonomi. Raja Grafindo Persada. Jakarta

Hamid, Edy Suandi. 2006. Ekonomi Indonesia dari Sentralisasi ke Desentralisai. UII Press: Yogyakarta.

Kuncoro, Mundrajad. 2003. Ekonomi Pembangunan: Teori, Masalah dan Kebijakan. UUP AMP-YKPN. Yogyakarta.

Samuelson, Paul A. dan Nordhaus, William D. 1994. Ekonomi. Erlangga. Jakarta.

Natsir, M. 2008. Peranan Jalur Suku Bunga dalam Mekanisme Transmisi Kebijakan moneter di Indonesia .Kendari : Program Pascasarjana Fakultas Ekonomi Unhalu. Kendari.

Tambunan, Tulus. 2012. Memahami Krisis: Siasat Membangun Kebijakan Ekonomi. LP3ES. Jakarta 